\title{
COMPOSITION, HOT-WATER SOLUBILITY OF ELEMENTS AND NUTRITIONAL VALUE OF FRUITS AND LEAVES OF YERBA MATE
}

\author{
Composição, solubilidade de elementos em água quente e valor \\ nutricional de frutos e folhas de erva-mate
}

\author{
Julierme Zimmer Barbosa ${ }^{1}$, Leandro Moraes Zambon ${ }^{2}$, Antonio Carlos Vargas Motta $^{2}$, Ivar Wendling ${ }^{3}$
}

\begin{abstract}
Yerba mate leaves are the most studied and used parts of the tree, while fruits have been little investigated as to their elemental composition. The objective of this study was to characterize the composition, the hot-water solubility of the elements and the nutritional value of yerba mate (Ilex paraguariensis St. Hill) fruits and leaves. Both fruits and leaves were collected from four yerba mate provenances (cities of Cascavel, Quedas do Iguaçu and Ivaí in Paraná state and Barão de Cotegipe in Rio Grande do Sul state) 17 years of age, grown in the city of Pinhais, Paraná state, Brazil. The total and hot water-soluble contents of 22 and 20 elements, respectively, were determined. The elemental composition of the fruits presented the following decreasing order: $\mathrm{C}, \mathrm{K}, \mathrm{N}, \mathrm{Mg}, \mathrm{Ca}$, $\mathrm{P}, \mathrm{Al}, \mathrm{Na}, \mathrm{Zn}, \mathrm{Mn}, \mathrm{Fe}, \mathrm{Ba}, \mathrm{Cu}, \mathrm{Ni}, \mathrm{Mo}, \mathrm{Pb}, \mathrm{Cr}, \mathrm{As}, \mathrm{Co}, \mathrm{Ag}, \mathrm{V}$ and $\mathrm{Cd}$. For the leaves the decreasing order was: C, N, K, Ca, Mg, P, $\mathrm{Al}, \mathrm{Mn}, \mathrm{Na}, \mathrm{Fe}, \mathrm{Zn}, \mathrm{Ba}, \mathrm{Cu}, \mathrm{Ni}, \mathrm{Pb}, \mathrm{Cr}, \mathrm{Mo}, \mathrm{As}, \mathrm{Co}, \mathrm{Ag}, \mathrm{V}$ and $\mathrm{Cd}$. It was found than 2 to 8 elements in the fruit presented greater water solubility than in the leaves. In case of consumption via infusion of the fruits or leaves, there would be nutritive value for K, $\mathrm{Mg}, \mathrm{P}, \mathrm{Mn}, \mathrm{Cr}, \mathrm{Mo}, \mathrm{Cu}$ and $\mathrm{Zn}$, while consumption of capsules would have nutritive value only for Mn via the leaves. In general, the fruits have more distinct elemental composition, hot-water solubility and nutritional value than yerba mate leaves.
\end{abstract}

Index terms: Ionome; heavy metals; medicinal plants.

\section{RESUMO}

As folhas erva-mate são as partes mais estudadas e mais utilizadas para o consumo, enquanto os frutos são pouco estudados quanto à composição elementar. Assim, neste estudo, objetivou-se caracterizar a composição, a hidrossolubilidade dos elementos e o valor nutricional de frutos e folhas de erva-mate (Ilex paraguariensis St. Hill). Foram coletados frutos e folhas de árvores de quatro procedências de erva-mate (Cascavel, Quedas do Iguaçu, Ivaí estado do Paraná e Barão de Cotegipe do estado do Rio Grande do Sul) com 17 anos, cultivadas na cidade de Pinhais, estado do Paraná, Brasil. Foram determinados os teores totais e hidrossolúveis em água quente de 22 e 20 elementos, respectivamente. A composição elementar dos frutos apresentou a seguinte ordem decrescente: C, K, N, Mg, Ca, P, Al, Na, Zn, Mn, Fe, Ba, Cu, Ni, Mo, Pb, Cr, As, Co, Ag, V e Cd. Já, para as folhas, a ordem decrescente foi: C, $\mathrm{N}, \mathrm{K}, \mathrm{Ca}, \mathrm{Mg}, \mathrm{P}, \mathrm{Al}, \mathrm{Mn}, \mathrm{Na}, \mathrm{Fe}, \mathrm{Zn}, \mathrm{Ba}, \mathrm{Cu}, \mathrm{Ni}, \mathrm{Pb}, \mathrm{Cr}, \mathrm{Mo}, \mathrm{As}, \mathrm{Co}, \mathrm{Ag}, \mathrm{V}$ e Cd. Verificou-se que 2 de 8 elementos apresentaram maior hidrossolubilidade nos frutos que nas folhas. Caso a infusão dos frutos ou das folhas fosse consumida, teria valor nutritivo para $\mathrm{K}, \mathrm{Mg}, \mathrm{P}, \mathrm{Mn}, \mathrm{Cr}, \mathrm{Mo}, \mathrm{Cu}$ e Zn, enquanto o consumo de cápsulas contribuiria apenas para o Mn via folhas. Em geral, os frutos têm composição, solubilidade de elementos em água quente e valor nutricional diferente das folhas de erva-mate.

Termos para indexação: Ionoma; metais pesados; plantas medicinais.

\section{INTRODUCTION}

Yerba mate (Ilex paraguariensis St. Hill) is a tree native to the austral region of South America, being primarily found in the south of Brazil, in the north of Argentina, in Paraguay and in Uruguay (Bastos et al., 2007). Currently, Brazil is the largest producer of yerba mate, and the state of Rio Grande do Sul is the leading yerba mate producer $(51.5 \%)$, followed by Paraná $(37.9 \%)$, Santa Catarina (9.8\%) and Mato Grosso do Sul (0.7\%) (Instituto Brasileiro de Geografia e Estatística-IBGE, 2014).
In the countries of origin the most traditional forms of consuming yerba mate are in hot or cold infusions, regionally called chimarrão (mate) and tererê. The chimarrão, the most widely utilized form, consists of: putting about $50 \mathrm{~g}$ of yerba mate preparation ( $70 \%$ leaves and $30 \%$ stems) in a calabash gourd; adding hot water and drinking the infusion through a utensil called the chimarrão straw. But, tererê, which is similar to chimarrão, is make with infusion in cold water. Industrialized drinks on a large scale and food supplements have also been made from leaves and stems of yerba mate (Heck; Mejia, 2007). In

\footnotetext{
${ }^{1}$ Universidade Federal do Paraná/UFPR - Rua dos Funcionários - n. 1540 - 80035-050 - Curitiba - PR - Brasil - barbosajz@yahoo.com.br 2Universidade Federal do Paraná/UFPR - Curitiba - PR - Brasil

${ }^{3}$ Empresa Brasileira de Pesquisa Agropecuária/Embrapa - Embrapa Florestas - Colombo - PR - Brasil

Received in may 21, 2015 and approved in october 5, 2015
} 
addition, the pharmaceutical and cosmetic industries utilize yerba mate in the making of cosmetics and medicines (Burris et al., 2012).

According to the compilations of Heck and Mejia (2007) and Burris et al. (2012), the main biomolecules present in yerba mate, which have human health value are, polyphenols, xanthines, caffeoyl derivates and saponins. Those compounds are interesting, for example, for presenting antioxidant, anti-inflammatory, vasodilator and stimulant action. On the other hand, the knowledge of yerba mate elemental composition is also important to humans, keeping in mind that plants contain both classes, essential and toxic elements. Heinrichs and Malavolta (2001) verified that $\mathrm{K}, \mathrm{Mg}$ and $\mathrm{Mn}$ were the majority nutrients ingested with the yerba mate infusion (prepared with $70 \%$ leaves and $30 \%$ stems), being low ingestion of heavy metals. But in terms of contribution to the daily allowances recommended for healthy adults, Bastos et al. (2014) found that the young yerba mate leaves infusion contributed especially with $\mathrm{Cu}$ and $\mathrm{Mn}$. With regard to heavy metals, in the South American Common Market (MERCOSUL) there is legislation only to establish the maximum contents of $\mathrm{As}, \mathrm{Cd}$ and $\mathrm{Pb}$ allowed in yerba mate, which are of $0.6,0.4$ and $0.6 \mathrm{mg} \mathrm{kg}^{-1}$ (Diário Oficial da União-DOU, 2013).

The leaves are the most studied and most utilized parts of yerba mate, the fruits being little studied and with no utilization in products designed for human or even animal consumption. Yerba mate flowers from October to November and the fruits become ripe between December and May in the producing countries. Immature fruits are green and the ripe present a purplish-red coloration, $7 \mathrm{~mm}$ in breadth and containing four seeds. Comparing the studies by Berté et al. (2011) [leaves] and Cogoi et al. (2013) [ripe fruits], it can be found that lower contents of proteins, lipids, fibers, caffeine, theobromine and ash and, higher carbohydrate and moisture content occur in the fruit.
Furthermore, Cogoi et al. (2013) investigated the total contents of seven elements essential to humans $(\mathrm{K}, \mathrm{Ca}$, $\mathrm{Mg}, \mathrm{Fe}, \mathrm{Cu}, \mathrm{Zn}$ and $\mathrm{Na}$ ). However, studies encompassing the ionome (Baxter et al., 2012) and the nutritional value of yerba mate fruits are scarce in the literature, considering desirable elements (essential or beneficial to plants or animals) and undesirable (with intoxication risk).

Therefore, the objective of this study was to characterize the composition, the hot-water solubility of the elements and nutritional value of fruits and leaves of different yerba mate provenances.

\section{MATERIAL AND METHODS}

In 1997, a test of progenies of yerba mate was established in the city of Pinhais (PR) $\left(25^{\circ} 23^{\prime} 12.3\right.$ "' South latitude and $49^{\circ} 07^{\prime} 33.2$ West longitude), in the state of Paraná, Brazil. The climate of the region is of the $\mathrm{Cfb}$ climate type (Humid subtropical; oceanic climate, without a dry season with temperate summer), according to the Köppen classification, the average minimum temperature is $16.2^{\circ} \mathrm{C}$ and maximum is $25.9^{\circ} \mathrm{C}$. Since the establishment of the herbal garden, the plants have grown in the full sunshine. The physical and chemical attributes of the soil (collected in the 0-20 cm layer in March of 2014) of the experimental area are in Table 1 and were analyzed according to the methodologies reported by Empresa Brasileira de Pesquisa Agropecuária-Embrapa (2011).

After 17 years; in March 2014, trees (progeny) of four provenances were selected: namely - Cascavel, Quedas do Iguaçu, Ivaí from Paraná state and Barão de Cotegipe from Rio Grande do Sul state. On two female plants of each provenance, both mature leaves and fruits were collected from the middle third of the crown and in all directions (north, south, east and west). The samples were washed with deionized water and dried in an oven at $65^{\circ} \mathrm{C}$ for $96 \mathrm{~h}$. Later, leaves and fruits were ground with a Wiley mill and passed through a $1 \mathrm{~mm}$ sieve.

Table 1: Soil chemical and physical attributes $(0-20 \mathrm{~cm})$ of the experimental area.

\begin{tabular}{|c|c|c|c|c|c|c|c|c|c|c|c|c|}
\hline $\mathrm{pH}$ & $\mathrm{Ca}^{2+}$ & $\mathrm{Mg}^{2+}$ & $\mathrm{K}^{+}$ & $\mathrm{Al}^{3+}$ & $\mathrm{H}+\mathrm{Al}$ & CEC & Base saturation & $\mathrm{OC}$ & $\mathrm{P}$ & Sand & Silt & Clay \\
\hline $\mathrm{CaCl}_{2}$ & \multicolumn{6}{|c|}{ 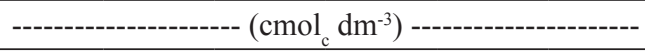 } & $\%$ & $\left(\mathrm{~g} \mathrm{dm}^{-3}\right)$ & $\left.(\mathrm{mg} \mathrm{dm})^{-3}\right)$ & \multicolumn{3}{|c|}{------- \% ------- } \\
\hline 4.2 & 4.0 & 2.2 & 0.13 & 1.8 & 6.2 & 12.5 & 50.6 & 30 & 10 & 41 & 22 & 37 \\
\hline $\mathrm{Fe}$ & $\mathrm{Mn}$ & $\mathrm{Cu}$ & $\mathrm{Zn}$ & $\mathrm{Pb}$ & $\mathrm{V}$ & $\mathrm{Cr}$ & As & $\mathrm{Ni}$ & Co & $\mathrm{Cd}$ & Mo & $\mathrm{Ag}$ \\
\hline \multicolumn{10}{|c|}{ 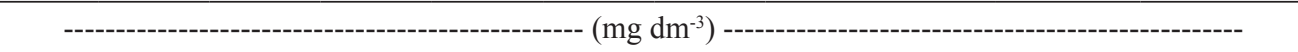 } & \multicolumn{3}{|c|}{$---\left(\mu \mathrm{g} \mathrm{dm}^{-3}\right)$--- } \\
\hline 77 & 11 & 1.3 & 1.0 & 1.2 & 0.25 & 0.13 & 0.11 & 0.09 & 0.07 & 6.6 & 4.8 & 1.4 \\
\hline
\end{tabular}

$\mathrm{pH}\left(\mathrm{CaCl}_{2} 0.01 \mathrm{~mol} \mathrm{~L}{ }^{-1}\right) ; \mathrm{Ca}^{2+}, \mathrm{Mg}^{2+}, \mathrm{Al}^{3+}$ (extracted with $\left.\mathrm{KCl} 1 \mathrm{~mol} \mathrm{~L}^{-1}\right) ; \mathrm{H}^{+}+\mathrm{Al}^{3+}$ (calcium acetate 0.5 mol $\mathrm{L}^{-1}$ extraction); organic carbon (OC) (volumetric method by potassium dichromate); $\mathrm{K}^{+}, \mathrm{P}, \mathrm{Mn}, \mathrm{Fe}, \mathrm{Cu}$ and $\mathrm{Zn}$ (Mehlich-1 extraction; soil:solution ratio 1:10), Pb, V, Cr, As, Ni, Co, Cd, Mo and Ag (Mehlich-1 extraction; soil:solution ratio 1:5); sand, silt and clay (method hydrometer).

Ciênc. Agrotec., Lavras, v. 39, n. 6, p. 593-603, nov./dez., 2015 
The $\mathrm{C}$ and $\mathrm{N}$ contents in the leaves and fruits were determined by dry combustion with nonmetal element analyzer (Elementar, Vario EL III), using about $15 \mathrm{mg}$ of ground plant material. For analysis of the other elements the Martins and Reissmann (2007) adapted methodology was used. About $2 \mathrm{~g}$ of ground plant material were ashed in porcelain crucibles in muffle furnace under $500{ }^{\circ} \mathrm{C}$ for 4 hours. After cooling of the crucibles, the ash was digested with $3 \mathrm{~mol} \mathrm{~L}^{-1} \mathrm{HCl}$ and the crucibles remained in the muffle at $500{ }^{\circ} \mathrm{C}$ for 4 more hours, after $10-\mathrm{ml}$ of $3 \mathrm{~mol} \mathrm{~L}^{-1} \mathrm{HCl}$ were then added and the crucibles remained for 10 minutes on a hot plate at $70{ }^{\circ} \mathrm{C}$. After this period, the digestion solutions were filtered in filter paper (pore diameter $8 \mu \mathrm{m}$ ) and the extracts collected in $50-\mathrm{ml}$ volumetric flasks. To gauge the volumetric flasks, deionized water was used. In the obtained extracts the following were determined: $\mathrm{K}$ and $\mathrm{Na}$ with flame emission spectrometer (Digimed, MD-62); P with UV-VIS spectrometer (Bel Photonics, SP2000), colorimetry via ammonium molybdate-vanadate; $\mathrm{Ca}, \mathrm{Mg}, \mathrm{Fe}, \mathrm{Mn}, \mathrm{Zn}, \mathrm{Cu}$, and $\mathrm{Al}$ with atomic absorption spectrometer (Varian, AA240FS) and $\mathrm{Mo}, \mathrm{Ni}, \mathrm{Co}, \mathrm{Pb}, \mathrm{Ag}$, $\mathrm{Cd}, \mathrm{As}, \mathrm{Ba}, \mathrm{Cr}$ and $\mathrm{V}$ with optical emission spectrometer with inductively coupled plasma (ICP-OES) (Varian, 720ES). Each sample was analyzed in duplicate.

For obtaining the water-soluble elements of the samples, infusion in hot water was performed. In 100$\mathrm{ml}$ porcelain crucibles $10 \mathrm{~g}$ of the material were added and then $80-\mathrm{ml}$ of deionized water at $100{ }^{\circ} \mathrm{C}$. After 3 minutes, the extract was filtered in filter paper (pore diameter $21 \mu \mathrm{M}$ ). A $20-\mathrm{ml}$ aliquot of the filtered extract was transferred to a porcelain crucible, which was placed on a hot plate $\left(70^{\circ} \mathrm{C}\right)$ until the filtrate was completely evaporated. Next, the residue was subjected to digestion in a muffle and to ash solubilization with $3-\mathrm{mol} \mathrm{L}^{-1} \mathrm{HCl}$ according to the methodology described for the analysis of the total contents of elements. In the extracts obtained, $\mathrm{K}$ and $\mathrm{Na}$ were determined by flame spectrophotometry, $\mathrm{P}$ by colorimetry via ammonium molybdate-vanadate; $\mathrm{Ca}$, $\mathrm{Mg}, \mathrm{Fe}, \mathrm{Mn}, \mathrm{Zn}, \mathrm{Cu}$ and $\mathrm{Al}$ by atomic absorption and $\mathrm{Mo}$, $\mathrm{Ni}, \mathrm{Co}, \mathrm{Pb}, \mathrm{Ag}, \mathrm{Cd}, \mathrm{As}, \mathrm{Ba}, \mathrm{Cr}$ and V by ICP-OES. Each sample was analyzed in duplicate. On the basis of the total contents and the water-soluble contents, the water-soluble fraction of each element was calculated.

All the determined elements, with the exception of C, were summed to obtain the ionome of the leaves and fruits of the four yerba mate provenances. On the other hand, on the basis of the total contents and the water-soluble fraction of each element, the content of the element in the infusion of 50 $\mathrm{g}$ of leaves or fruits was calculated. Additionally, on the basis of the total contents, the content of the element in $500 \mathrm{mg}$ of leaves or fruits was calculated. The amount of $50 \mathrm{~g}$ and $500 \mathrm{mg}$ was chosen for effect of standardization, because they are equivalent to the average consumption of yerba mate preparation via chimarrão (Heck; Mejia, 2007) and to the content in one capsule, respectively. With the content (mean of the four provenances) the contribution of each element to the indexes of recommended dietary allowances (RDA) and tolerable upper intake (TUI), established internationally (Who, 1996; Institute of Medicine-IOM, 2001; Food Standards Agency-FSA, 2003; Scher, 2012) was determined. There are no data on the acceptable intake for humans only for the element $\mathrm{Ag}$, so the value utilized refers to the sum of the average intake of Ag with the standard deviation $\left(27+17=44 \mu\right.$ day $\left.^{-1}\right)$ (Hamilton; Minski, 1973).

\section{RESULTS AND DISCUSSION}

The dry matter (DM) weight of 100 leaves ranged from 18.3 to $25.0 \mathrm{~g}$ and the DM of 100 fruits ranged from 4.3 to $5.1 \mathrm{~g}$ (Figure 1A). This result corroborates visual inspection, since leaves are larger than fruits. The Quedas do Iguaçu showed to be the heaviest leaves among the four provenances studied.

The ionome from the two evaluated plant tissues varied among the provenances. Barão de Cotegipe presented greater ionome in leaves than fruits, while the ionome of leaves and fruits from Cascavel, Ivaí and Quedas do Iguaçu provenances presented higher variation (Figure 1B). In general low yerba mate leaf ionome values were found (32-37 $\left.\mathrm{g} \mathrm{kg}^{-1}\right)$. These values were below the range of values $\left[40-72 \mathrm{~g} \mathrm{~kg}^{-1}\right.$; sum of total $\mathrm{N}, \mathrm{P}, \mathrm{K}, \mathrm{Ca}$, $\mathrm{Mg}, \mathrm{Fe}, \mathrm{Mn}, \mathrm{Cu}, \mathrm{B}, \mathrm{Zn}$ and $\mathrm{Al}]$ observed by Reissmann, Radomski and Quadros (1999), who studied yerba mate plants from seven localities of the state of Paraná. Growing in full sun may have been one of the factors responsible for the low ionome values in our study. In this sense, Caron et al. (2014) noted that the sum of N, P, K, Ca, Mg and Fe in the yerba mate leaves grown under full sun was lower (43 $\left.\mathrm{g} \mathrm{kg}^{-1}\right)$ than in the shaded growing $\left(60 \mathrm{~g} \mathrm{~kg}^{-1}\right)$. This can occur due to the yerba mate not being found, natively, under full sun conditions, thus, this condition would affect the transpiration, physiology and elements utilization by the plants. However, other environmental factors may have contributed to the elemental composition values of mate that were recorded, such as soil fertility, water availability and natural enemies. Specifically with regard to soil fertility, it is worth noting that although it has high acidity, the soil of the field has adequate $\mathrm{Ca}^{2+}$ and $\mathrm{Mg}^{2+}$ availability (Table 1), which can commonly be related to the presence of 2:1 of the minerals in kaolinitic soils (Silva et al., 2008). Thus, the high $\mathrm{Ca}^{2+}$ and $\mathrm{Mg}^{2+}$ may affect the 
absorption of other cations by changing the ionome values. Furthermore, the leaves may have presented low values ionome due to remobilization of some elements from the leaves to the fruit.

In general, the total contents were lower for 9 elements evaluated in the fruits, compared with the leaves, of the yerba mate provenances (Figure 2). In opposition, $\mathrm{K}$ content was higher in the fruit than in the leaves. For $\mathrm{Mn}, \mathrm{Ba}, \mathrm{Ca}, \mathrm{Fe}, \mathrm{Cr}$ and $\mathrm{Al}$ the differences ranged between $-89 \%$ to $-41 \%$, while for $\mathrm{N}, \mathrm{Mg}$ and $\mathrm{Ag}$ the differences ranged between $-31 \%$ to $-12 \%$. Despite the wide variation in results, $\mathrm{As}, \mathrm{Cu}$, $\mathrm{Mo}$ and $\mathrm{Na}$ showed the same trend, i.e., lower levels in fruits than in leaves. By contrast, fruits presented $\mathrm{K}$ contents between 139 and $64 \%$ higher than leaves.

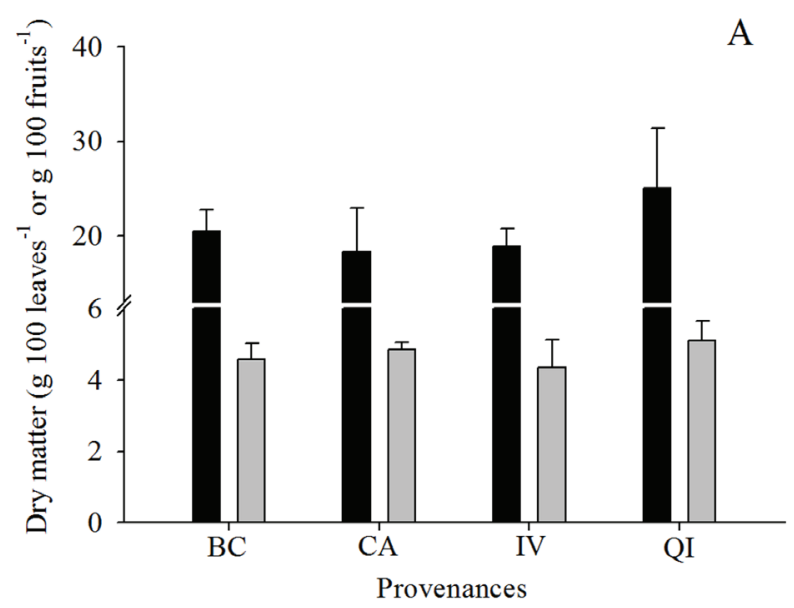

The transportation of metals to fruits is generally low in the several species used for human consumption, since in tea (Camellia sinensis L.), Kröppl et al. (2012) observed lower Al content in fruits compared with leaves. In coffee, Santos et al. (2009) observed that lower $\mathrm{Cu}$, $\mathrm{Zn}$ and $\mathrm{Cd}$ content in fruits compared with leaves. The transportation of elements via xylem to fruits is strongly influenced by transpiration and xylem flow volume, since decreased transportation generally occurs in fruits with low values for these attributes (White, 2012). Since transportation via phloem depends on the element mobility, $\mathrm{Ca}$ and $\mathrm{Mn}$ are known as elements of very poor mobility. Therefore, the low concentration of $\mathrm{Ca}, \mathrm{Mn}, \mathrm{Fe}, \mathrm{Ba}, \mathrm{Cr}$, $\mathrm{Al}$ and $\mathrm{Ag}$ in the fruits may be associated with the low influx to them and the low redistribution by the phloem.

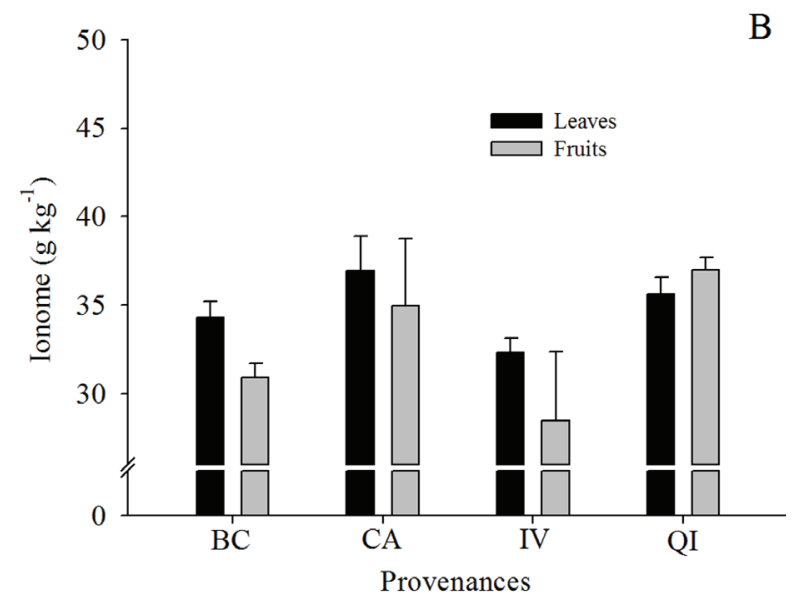

Figure 1: Dry matter (A) and ionome (B) in fruits and leaves of provenances of yerba mate grown at Pinhais-Paraná, Brazil. BC-Barão de Cotegipe; CA-Cascavel; IV-Ivaí; QI-Quedas do Iguaçu. Bars indicate the standard deviation.

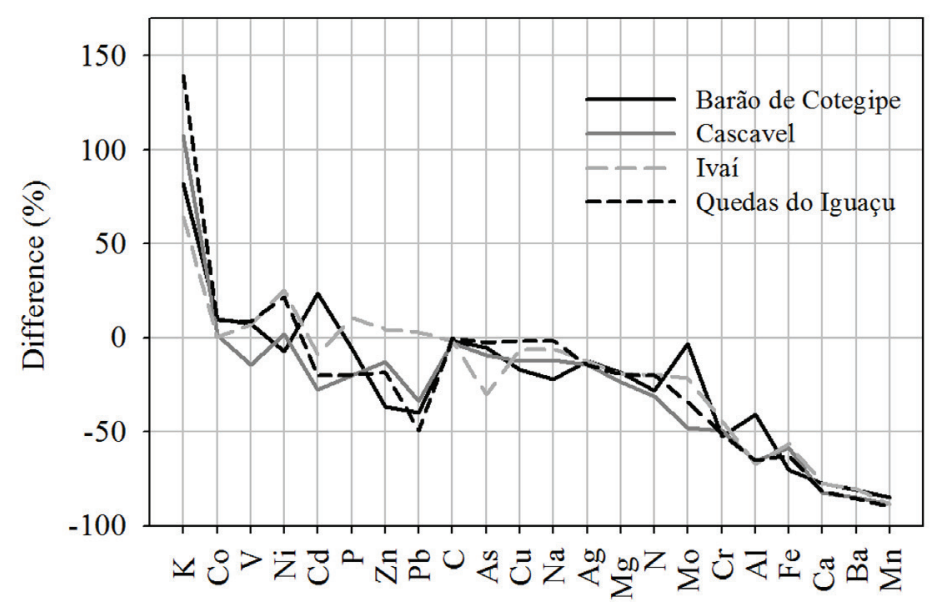

Figure 2: Difference (\%) of the total contents of elements in fruit, in relation to leaves of yerba mate grown in the city of Pinhais - Paraná State, Brazil. 
In contrast, $\mathrm{N}, \mathrm{P}, \mathrm{K}$ and $\mathrm{Mg}$ have been regarded as mobile in the majority of cultivated plants. However, the mobile nutrients in the phloem may present reduced transportation when they do not have good remobilization in the source organs (White, 2012). In the case of $\mathrm{N}$ and $\mathrm{Mg}$, which showed low levels in yerba mate fruit, the remobilization in source organs to the fruit might have influenced the results, in addition to the carry-over effect via xylem. However, the elements in the leaves are engaged (directly or indirectly) in a series of reactions related to photosynthesis and respiration, whereas the mate fruit seed is the main portion (in terms of dry mass). Thus, differences in the elemental composition can also be an inherent function of each plant organ. Thus, the ratios among transportation of elements (xylem and phloem), remobilization in the source organs and function affect the composition of the fruit, since in yerba mate, there appears to be a limit to the entry of various elements into the reproductive organs.

The contents determined of the 22 elements and the $\mathrm{C} / \mathrm{N}$ ratio of fruits and leaves are found in Table 2. The results obtained point out that the fruits presented lower $\mathrm{N}$ contents and little variation in the $\mathrm{C}$ contents in relation to the leaves, as well as a high $\mathrm{C} / \mathrm{N}$ ratio. The highest $\mathrm{C} / \mathrm{N}$ ratio can be related to the resistant and lignified tissue involving the yerba mate seed, and because fruits contain lower protein values and higher carbohydrate values than leaves (Berté et al., 2011; Cogoi et al., 2013).

Concurrently, the low ionome contents observed in yerba mate leaves (Figure 1B) are mainly related to the macronutrients $\mathrm{N}$ and $\mathrm{K}$. Since $\mathrm{N}$ and $\mathrm{K}$ were the elements that contributed the most to ionome, these nutrients presented less content than that recorded by Reissmann et al. (1999) in a characterization study of the elemental composition in yerba mate leaves. In addition, the $\mathrm{Mn}$ also presented low content, but the contents of $\mathrm{Ca}, \mathrm{Fe}, \mathrm{Zn}, \mathrm{Cu}$ and $\mathrm{Al}$ in the leaves stayed within the range of contents reported by the above mentioned study. The Mo and Co concentrations were in agreement with values under $1 \mathrm{mg} \mathrm{kg}^{-1}$, indicated by Heinrichs and Malavolta (2001). In contrast, Ni stayed above the same value indicating a greater efficiency in its absorption by the yerba mate plant, since the values found in soil were low (Table 1). The Mn, Zn, Ni, Mo and $\mathrm{Ba}$ values were those which presented the greatest variations among provenances, indicating that there may be difference in absorption capacity.
Considering heavy metals, only $\mathrm{As}, \mathrm{Cd}$ and $\mathrm{Pb}$ are within the acceptable maximum content established by Brazilian legislation for yerba mate, which are 0.6 , 0.4 and $0.6 \mathrm{mg} \mathrm{kg}^{-1}$ (Dou, 2013). We observed that only $\mathrm{Pb}$ in the leaves reached the critical level allowed, with $0.61 \mathrm{mg} \mathrm{kg}^{-1}$ in the Quedas do Iguaçu provenance (Table 2). The observed contents for $\mathrm{Pb}$ were similar to the $0.3-0.6 \mathrm{mg} \mathrm{kg}^{-1}$ range found by Vulcano, Silveira and Alvarez-Leite (2008) in yerba mate leaves, but the values observed were low if compared to the $2.19 \mathrm{mg}$ $\mathrm{kg}^{-1}$ average and range of 0.59 to $4.49 \mathrm{mg} \mathrm{kg}^{-1}$ reported by Jin et al. (2005) for tea leaf samples collected in 17 plantations in China. The same authors concluded that the high $\mathrm{Pb}$ content for leaves was the result of the combination of low $\mathrm{pH}$ (high acidity - average $\mathrm{pH} 3.71$ ) and high $\mathrm{Pb}$ availability $\left(3.81 \mathrm{mg} \mathrm{kg}^{-1}\right)$. Although the soil acidity was high in this study, the $\mathrm{Pb}$ availability was much lower compared to soil used by Jin et al. (2005) (Table 1). On the other hand, the fruits showed a $\mathrm{Pb}$ content around 50\% lower than in leaves, also below the maximum content reported by Schmidt et al. (2009) in coffee fruits $\left(2.7 \mathrm{mg} \mathrm{kg}^{-1}\right)$. The element $\mathrm{Ag}$ is a heavy metal undesirable at high content (Hamilton; Minski, 1973), and in spite of that, it does not possess maximum levels allowed by Brazilian legislation. However, in the yerba mate fruit and leaves contents under $0.22 \mathrm{mg}$ $\mathrm{kg}^{-1}$ were recorded, i.e.,content below that permitted for $\mathrm{Pb}$, As and $\mathrm{Cd}$.

The results point out that $\mathrm{Ca}, \mathrm{Ba}, \mathrm{Fe}$ and $\mathrm{Al}$ presented hot-water solubility lower or close to $20 \%$ in leaves (Figure 3). Therefore, with the exception of $\mathrm{Cr}$, the results point to lower mobility presented earlier (Figure 2). Corroborating the result of this study, Heinrichs and Malavolta (2001), in evaluating industrialized yerba mate samples, report that the elements with lower water-solubility were $\mathrm{N}, \mathrm{Ca}$ and $\mathrm{Fe}$, indicating strong interaction with the organic fraction, that is, $\mathrm{N}$ and $\mathrm{Fe}$ being in protein formation, while $\mathrm{Ca}$ is held in pectates of the cell wall (Koolman; Roehm, 2005). Similarity between $\mathrm{Ba}$ and $\mathrm{Al}$ has been reported by the literature as to the adsorption capacity in pectates and organic compounds (Metraux; Taiz, 1977; McKenna et al., 2010), which may have influenced the low watersolubility of these elements. However, $\mathrm{Cu}$ which also presents a strong interaction with the pectin matrix did not have poor water-solubility in our study (Figure 3) nor in the study by Heinrichs and Malavolta (2001), indicating that for this element the bond becomes weak with infusion in hot-water. 
Table 2: Total content of elements (mean \pm standard deviation) in leaves and fruits of provenances of yerba mate grown at Pinhais - Paraná, Brazil.

\begin{tabular}{|c|c|c|c|c|c|c|c|c|}
\hline \multirow{2}{*}{ leme } & \multicolumn{2}{|c|}{ Barão de Cotegipe } & \multicolumn{2}{|c|}{ Cascavel } & \multicolumn{2}{|c|}{ Ivaí } & \multicolumn{2}{|c|}{ Quedas do Iguaçu } \\
\hline & (2) & cuits & aves & Frouts & & Fruits & es & ts \\
\hline $\mathrm{C} / \mathrm{N}$ & & & & & .2 & 8 & 1.9 & \\
\hline $\mathrm{C}\left(\mathrm{g} \mathrm{kg}^{-1}\right)$ & & t & & & & & $469 \pm 14$ & \\
\hline $\mathrm{N}\left(\mathrm{g} \mathrm{kg}^{-1}\right)$ & $.51 \pm 1.5$ & $.14 \pm 0.9$ & $15.88 \pm 1.1$ & $10.94 \pm 0.7$ & $13.38 \pm 0.9$ & $10.72 \pm 0.6$ & $15.64 \pm 1.2$ & $12.50 \pm 1.0$ \\
\hline $\mathrm{K}(\mathrm{g}$ & $89 \pm 0.74$ & $14.37 \pm 0.55$ & $9.18 \pm 0.91$ & $19.05 \pm 3.6$ & $7.44 \pm 0.89$ & $12.24 \pm 3.4$ & $8.21 \pm 0.93$ & $19.6 \pm 0.71$ \\
\hline $\mathrm{Ca}(\mathrm{g}$ & $77 \pm 0.34$ & $1.31 \pm 0.29$ & $6.56 \pm 0.25$ & $1.13 \pm 0.13$ & $6.80 \pm 0.22$ & $1.52 \pm 0.40$ & $6.51 \pm 0.45$ & $1.17 \pm 0.09$ \\
\hline $\operatorname{Mg}\left(\mathrm{g} \mathrm{kg}^{-1}\right)$ & $.71 \pm 0.01$ & $2.20 \pm 0.15$ & $2.71 \pm 0.01$ & $2.07 \pm 0.06$ & $2.72 \pm 0.01$ & $2.20 \pm 0.09$ & $2.73 \pm 0.02$ & $2.19 \pm 0.01$ \\
\hline $\mathrm{P}\left(\mathrm{g} \mathrm{kg}^{-1}\right)$ & & $1.55 \pm 0.10$ & $1.98 \pm 0.94$ & $1.58 \pm 0.35$ & $1.53 \pm 0.18$ & $1.59 \pm 0.21$ & $2.12 \pm 0.24$ & $1.70 \pm 0.19$ \\
\hline $\mathrm{Fe}\left(\mathrm{mg} \mathrm{kg}^{-1}\right)$ & $54.1 \pm 2.5$ & & & & & & & \\
\hline $\operatorname{Mn}\left(\mathrm{mg} \mathrm{kg}^{-1}\right)$ & 2 & & 1 & & & & $157.7 \pm 27$ & \\
\hline $\mathrm{Zn}(\mathrm{n}$ & & & & & & & & \\
\hline $\mathrm{Cu}(\mathrm{m}$ & & & & & & & & \\
\hline $\mathrm{Ni}(\mathrm{m}$ & & 1 & 011 & 0 & & & 1.29 & 1.5 \\
\hline Mo (1 & $0.35 \pm 0.06$ & $0.29 \pm 0.10$ & $0.82 \pm 0.52$ & $0.43 \pm 0.14$ & $0.42 \pm 0.02$ & $0.33 \pm$ & $0.48 \pm 0.01$ & $0.32 \pm 0.01$ \\
\hline $\mathrm{Co}\left(\mathrm{mg} \mathrm{kg}^{-1}\right)$ & $0.25 \pm 0.02$ & $0.27 \pm 0.01$ & $0.25 \pm 0.01$ & $0.25 \pm 0.02$ & $0.26 \pm 0.03$ & $0.26 \pm 0.01$ & $0.23 \pm 0.01$ & $0.25 \pm 0.02$ \\
\hline $\mathrm{Na}\left(\mathrm{mg} \mathrm{kg}^{-1}\right)$ & $224 \pm 43$ & $174 \pm 43$ & $10 \pm 11$ & $273 \pm 12$ & $423 \pm 23$ & $397 \pm 21$ & $372 \pm 19$ & $366 \pm 20$ \\
\hline $\mathrm{Al}\left(\mathrm{mg} \mathrm{kg}^{-1}\right)$ & .5 & & & & & & & $121 \pm 38$ \\
\hline $\mathrm{Ba}\left(\mathrm{mg} \mathrm{kg}^{-1}\right)$ & $55.4 \pm 19$ & $10.6 \pm 0.6$ & & & & & $28.1 \pm 7.8$ & \\
\hline $\mathrm{Pb}\left(\mathrm{mg} \mathrm{kg}^{-1}\right)$ & & & & & & & & 0.3 \\
\hline $\mathrm{Cr}\left(\mathrm{mg} \mathrm{kg}^{-1}\right)$ & & & 9 & & & & 0.57 & 0.28 \\
\hline As $\left(m g \mathrm{~kg}^{-1}\right)$ & & $0.32 \pm$ & $2 \pm 0.12$ & $0.19 \pm$ & 048 & 0.33 & $0.39 \pm$ & $0.38 \pm 0.16$ \\
\hline $\mathrm{Ag}\left(\mathrm{mg} \mathrm{kg}{ }^{-1}\right)$ & $0.22 \pm 0.02$ & $0.20 \pm 0.02$ & $0.22 \pm 0.01$ & $0.19 \pm 0.01$ & $0.22 \pm 0.01$ & $0.20 \pm 0.01$ & $0.22 \pm 0.01$ & $0.18 \pm 0.01$ \\
\hline $\mathrm{V}(\mathrm{mg}$ & 1 & 0.1 & $0.20 \pm$ & 0.01 & $0.16 \pm 0.01$ & 0.17 & $0.16 \pm 0.02$ & $0.18 \pm 0.01$ \\
\hline $\mathrm{Cd}\left(\mathrm{mg} \mathrm{kg}^{-1}\right)$ & $0.12 \pm 0.02$ & $0.16 \pm 0.01$ & $0.13 \pm 0.03$ & $0.10 \pm 0.01$ & $0.12 \pm 0.02$ & $0.11 \pm 0.02$ & $0.14 \pm 0.01$ & $0.11 \pm 0.02$ \\
\hline
\end{tabular}

In general, it was found that $\mathrm{Fe}$ and $\mathrm{Al}$ had greater hot-water solubility in fruits than in leaves, being that $\mathrm{Ca}$, $\mathrm{Zn}, \mathrm{Mo}, \mathrm{Pb}, \mathrm{Ag}$ and $\mathrm{Cd}$ presented similar behavior, but with variation between provenances (Figure 3 ). The higher solubility of elements in the fruit indicates that they are accumulated in more labile forms in the fruit. These results must have a relation to the yerba mate fruits containing lower protein, fat, fiber, caffeine and theobromine content and higher carbohydrate content as compared to leaves (Berté et al., 2011; Cogoi et al., 2013). In proteins, N, S, $\mathrm{P}, \mathrm{Fe}, \mathrm{Zn}$ and $\mathrm{Se}$ are the quantitatively most important elements, for being part of the protein structure, but the 
charge residues in the chemical groups of proteins also enable the retaining of elements (Koolman et al., 2005). Karak and Bhagat (2010) reported that polyphenols were another group of biomolecules capable of retaining elements, especially metals. In this sense, lower protein and polyphenol content could reduce the bond strength of some elements, making these elements more water soluble in yerba mate fruits. In addition, the high solubility of some elements in the fruit could be related to the presence of free elements in the pulp or for easy extraction forms, being more easily removed by hot water.

In general, the contribution of the infusion of fruits and leaves to the RDA ranged from 116 to $0.92 \%$, while for the TUI index, the contribution varied between 12.46 and $0.38 \%$ (Table 3 ). Among the five elements required in larger quantities $(\mathrm{K}, \mathrm{Na}, \mathrm{Ca}, \mathrm{Mg}$, and $\mathrm{P})$, three of them $(\mathrm{K}$, $\mathrm{Mg}$, and $\mathrm{P}$ ) might be supplied by fruit and leaf infusions, varying between 18.1 and $8.7 \%$ of necessity. Similarly, Bastos et al. (2014) indicated the same three elements from young yerba mate leaves as the highest contributors to the daily intake.
In relation to those elements required in small quantities $\mathrm{Mn}, \mathrm{Cr}, \mathrm{Mo}, \mathrm{Cu}, \mathrm{Zn}$ and $\mathrm{Fe}$ stand out and for the infusion of leaves presented 116, 60, 29, 27.8, 6.1 and 1.2\% of contribution to the RDA, while with the infusion of the fruits, the contribution was $22,36,33,20,8.3$ and $1.9 \%$, respectively (Table 3 ). The results reported by Heinrichs and Malavolta (2001) with yerba mate preparation for chimarrão ( $70 \%$ leaves and $30 \%$ of stems) indicate contribution above the RDA for Mn. However, this was based on leaves with low Mn contents (129-232 mg kg-1) (Table 2). Reissmann et al. (1999) found wide variation in the Mn content (346$3330 \mathrm{~m} \mathrm{~kg}^{-1}$ ) in samples of yerba mate leaves from seven places in the state of Paraná, Brazil. Thus, in leaf samples with high Mn levels, greater attention should be paid to the contribution to the daily intake rates, especially with TUI index. Hope et al. (2006) found that in the infusion of black tea leaves Mn content is commonly found exceeding the RDA value, and in some cases even exceeding the TUI. The low contribution of fruits to the RDA, as compared with leaves, is related to the Mn contents in the fruits being $88 \%$ lower than the leaf content (Figure 2). Other studies

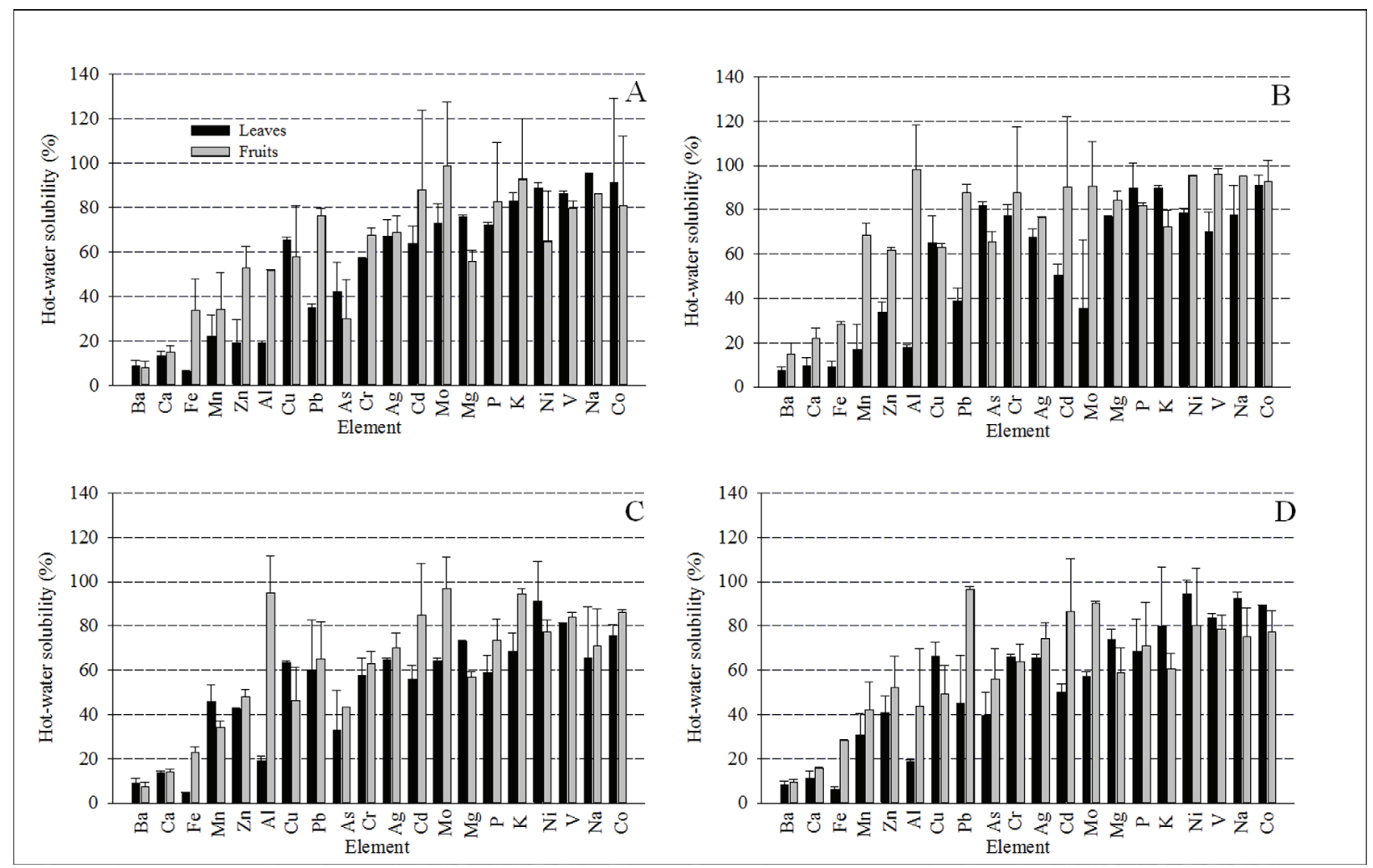

Figure 3: Hot-water solubility (\%) of elements in leaves and fruits of provenances of yerba mate grown in Pinhais Paraná State, Brazil. A = Barão do Cotegipe; $\mathrm{B}=$ Cascavel; $\mathrm{C}=$ Ivaí; $\mathrm{D}=$ Quedas do Iguaçu. Bars indicate the standard deviation. 
have pointed out a high contribution from the intake of medicinal plant infusions for the element $\mathrm{Cr}$. Analyzing the infusion of 56 Chinese Pu-erh samples (prepared from black tea leaves), Lv et al. (2013) reported contributions of up to $96 \%$ to the daily requirements of $\mathrm{Cr}$. Furthermore, leaf or fruit infusions also contribute to the intake of Mo, $\mathrm{Cu}$ and $\mathrm{Zn}$. Thus, with this composition, leaves and fruits could contribute to the high $(\mathrm{K}, \mathrm{Mg}$, and $\mathrm{P})$ and low $(\mathrm{Mn}$, $\mathrm{Cr}, \mathrm{Mo}, \mathrm{Cu}$ and $\mathrm{Zn}$ ) element intake demand by the body.

In the infusion of the leaves, the element with the highest contribution to the TUI was Ba (13\%), whereas for fruits, it was $\mathrm{Cd}(8 \%)$ since on the average, the element contribution to the TUI was $5 \%$ for leaves and $4 \%$ for fruits (Table 3). In a broad review of trace element contents in black tea preparations, Karak and Bhagat (2010) report that $\mathrm{Al}, \mathrm{Cd}, \mathrm{Pb}$ and $\mathrm{F}$ are elements that may have high contribution to the acceptable daily intake. But, the authors point out that in addition to the total contents, it is important to know the speciation of the elements. In time, the heavy metal Ag does not present values considered tolerable by humans, however, using the average daily intake + standard deviation as a reference, we found that the contribution of the infusion of the leaves and fruits was of $16 \%$. Assessing the infusion of the shoots of chamomile species (Achyrocline ssp.) of South America, Vitto et al. (2009) found that $\mathrm{Al}$ and $\mathrm{Ba}$ were the elements which contributed the most via infusion (between 8.5 and $0.5 \%$ ), however, with null contribution by Ag.

Table 3: Content of elements (mean \pm standard deviation) in the infusion of yerba mate leaves and fruits (mean of provenances) and their contribution to the Recommended Dietary Allowances (RDA) and Tolerable Upper Intake (TUI) indices.

\begin{tabular}{ccrcccc}
\hline & \multicolumn{5}{c}{ Leaves } & \multicolumn{2}{c}{ Fruits } \\
\hline Elements & Index & Value & $\begin{array}{c}\text { Hot-water soluble } \\
\text { content in 50 g }\end{array}$ & $\begin{array}{c}\text { RDA or TUI } \\
\text { contribution } \\
(\%)\end{array}$ & $\begin{array}{c}\text { Hot-water soluble } \\
\text { content in } 50 \mathrm{~g}\end{array}$ & $\begin{array}{c}\text { RDA or TUI } \\
\text { contribution } \\
(\%)\end{array}$ \\
\hline $\mathrm{K}^{1}$ & & & & & \\
$\mathrm{Na}^{2}$ & RDA & $3500 \mathrm{mg}$ & $330 \pm 55 \mathrm{mg}$ & $9.2 \pm 1.6$ & $632 \pm 46 \mathrm{mg}$ & $18.1 \pm 1.3$ \\
$\mathrm{Ca}^{2}$ & RDA & $1300 \mathrm{mg}$ & $13 \pm 2 \mathrm{mg}$ & $1 \pm 0.15$ & $12 \pm 2.6 \mathrm{mg}$ & $0.92 \pm 0.2$ \\
$\mathrm{P}^{2}$ & RDA & $700 \mathrm{mg}$ & $38 \pm 5 \mathrm{mg}$ & $3.8 \pm 0.5$ & $10 \pm 1.2 \mathrm{mg}$ & $1.0 \pm 0.12$ \\
$\mathrm{Mg}^{2}$ & RDA & $370 \mathrm{mg}$ & $64 \pm 17 \mathrm{mg}$ & $9.3 \pm 2.4$ & $61 \pm 2.5 \mathrm{mg}$ & $8.7 \pm 0.36$ \\
$\mathrm{Fe}^{2}$ & RDA & $14 \mathrm{mg}$ & $0.17 \pm 0.03 \mathrm{mg}$ & $1.2 \pm 0.2$ & $0.27 \pm 0.01 \mathrm{mg}$ & $1.9 \pm 0.07$ \\
$\mathrm{Zn}^{2}$ & RDA & $9 \mathrm{mg}$ & $0.55 \pm 0.07 \mathrm{mg}$ & $6.1 \pm 0.8$ & $0.75 \pm 0.11 \mathrm{mg}$ & $8.3 \pm 1.2$ \\
$\mathrm{Mn}^{2}$ & RDA & $2.0 \mathrm{mg}$ & $2.32 \pm 0.60 \mathrm{mg}$ & $116 \pm 30$ & $0.45 \pm 0.16 \mathrm{mg}$ & $22.5 \pm 8$ \\
$\mathrm{Cu}^{2}$ & RDA & $0.90 \mathrm{mg}$ & $0.25 \pm 0.01 \mathrm{mg}$ & $27.8 \pm 1.1$ & $0.18 \pm 0.01 \mathrm{mg}$ & $20.0 \pm 1.1$ \\
$\mathrm{Mo}^{2}$ & RDA & $45 \mathrm{mg}$ & $13 \pm 0.6 \mathrm{mg}$ & $28.8 \pm 1.3$ & $16 \pm 1.7 \mathrm{mg}$ & $35.6 \pm 3.8$ \\
$\mathrm{Cr}^{2}$ & RDA & $30 \mathrm{mg}$ & $18 \pm 3.9 \mathrm{mg}$ & $60 \pm 13$ & $10 \pm 2.2 \mathrm{mg}$ & $33 \pm 7.3$ \\
$\mathrm{Al}^{3}$ & TUI & $65 \mathrm{mg}$ & $3 \pm 0.4 \mathrm{mg}$ & $4.61 \pm 0.62$ & $4.34 \pm 1 \mathrm{mg}$ & $6.67 \pm 1.5$ \\
$\mathrm{~V}^{2}$ & TUI & $1800 \mathrm{mg}$ & $7.11 \pm 0.2 \mathrm{mg}$ & $0.38 \pm 0.01$ & $7.61 \pm 0.4 \mathrm{mg}$ & $0.42 \pm 0.02$ \\
$\mathrm{Co}^{1}$ & TUI & $1400 \mathrm{mg}$ & $11 \pm 0.5 \mathrm{mg}$ & $0.78 \pm 0.04$ & $11 \pm 0.7 \mathrm{mg}$ & $0.78 \pm 0.05$ \\
$\mathrm{Ba}^{4}$ & TUI & $1300 \mathrm{mg}$ & $162 \pm 56 \mathrm{mg}$ & $12.4 \pm 4.3$ & $31 \pm 8 \mathrm{mg}$ & $2.38 \pm 0.62$ \\
$\mathrm{Ni}^{3}$ & TUI & $1000 \mathrm{mg}$ & $62 \pm 20 \mathrm{mg}$ & $6.2 \pm 2$ & $57 \pm 6.5 \mathrm{mg}$ & $5.7 \pm 0.65$ \\
$\mathrm{~Pb}^{3}$ & TUI & $250 \mathrm{mg}$ & $11 \pm 2 \mathrm{mg}$ & $4.40 \pm 0.80$ & $14 \pm 0.8 \mathrm{mg}$ & $5.60 \pm 0.32$ \\
$\mathrm{As}^{3}$ & TUI & $150 \mathrm{mg}$ & $8.01 \pm 0.6 \mathrm{mg}$ & $5.34 \pm 0.40$ & $7.37 \pm 2 \mathrm{mg}$ & $4.91 \pm 1.3$ \\
$\mathrm{Cd}^{3}$ & TUI & $65 \mathrm{mg}$ & $3.65 \pm 0.27 \mathrm{mg}$ & $5.61 \pm 0.42$ & $5.14 \pm 0.75 \mathrm{mg}$ & $7.90 \pm 1.1$ \\
$\mathrm{Ag}^{5}$ & - & $44 \mathrm{mg}$ & $7.42 \pm 0.17 \mathrm{mg}$ & $16.86 \pm 0.39$ & $7.02 \pm 0.20 \mathrm{mg}$ & $15.95 \pm 0.45$ \\
\hline
\end{tabular}

${ }^{1}$ Fsa (2003); ${ }^{2}$ Iom (2001); ${ }^{3}$ Who $(1996) ;{ }^{4}$ Scher $(2012) ;{ }^{5}$ There are no data on the intake acceptable to humans, so the indicated value refers to the sum of the average intake of Ag with the standard deviation $\left(27+17=44 \mu \mathrm{g}\right.$ day $\left.{ }^{-1}\right)$ according to Hamilton and Minski (1972). 
The content of elements in $500 \mathrm{mg}$ (equivalent to a common capsule) of leaves or fruits of yerba mate and their contributions to the RDA and TUI indexes are shown in Table 4. The leaves show nutritional value for $\mathrm{Mn}$ ( $4.25 \%$ of the RDA), whereas the fruit has no nutritional value. Reissmann et al. (1999) found wide variation in the Mn content (346-3330 mg kg-1) in samples of yerba mate leaves from seven places in Paraná State, Brazil. In this case, the ingestion of a capsule containing $500 \mathrm{mg}$ of leaves with the maximum value obtained by Reissmann et al. (1999) would contribute $83 \%$ of the RDA for Mn. This would also apply to black tea leaves, they can reach similar
Mn levels (174-3154 $\mathrm{mg} \mathrm{kg}^{-1}$ ) (Karak; Bhagat, 2010). On the other hand, considering the TUI of elements, only the $\mathrm{Ba}(1.49 \%)$ in the leaves showed a contribution higher than $1 \%$ in our study, therefore, an insignificant intake of undesirable elements. Additionally, contribution to the intake $\mathrm{Ag}$ was also less than $1 \%$. In contrast, evaluating 125 samples of herbals (involving nine medicinal herbs) marketed in the form of capsules, Caldas and Machado (2004) found negligible intake of $\mathrm{Pb}, \mathrm{Cd}$ and $\mathrm{Hg}$ in most products, except for three samples (total $=15$ samples) of horse chestnut (Aesculus hippocastanum) which exceeded the tolerable limits.

Table 4: Content of elements (mean \pm standard deviation) in $500 \mathrm{mg}$ of yerba mate leaves and fruits (mean of provenances) and their contribution to the Recommended Dietary Allowances (RDA) and Tolerable Upper Intake (TUI) indices.

\begin{tabular}{|c|c|c|c|c|c|c|}
\hline & & & Leaves & & Fruits & \\
\hline Elements & Index & Value & $\begin{array}{l}\text { Content in } \\
500 \mathrm{mg}\end{array}$ & $\begin{array}{l}\text { RDA or TUI } \\
\text { contribution }\end{array}$ & Content in $500 \mathrm{mg}$ & $\begin{array}{l}\text { RDA or TUI } \\
\text { contribution }\end{array}$ \\
\hline & & & & $(\%)$ & & $(\%)$ \\
\hline $\mathrm{K}^{1}$ & RDA & $3500 \mathrm{mg}$ & $4.09 \pm 0.31 \mathrm{mg}$ & $0.12 \pm(*)$ & $8.17 \pm 1.56 \mathrm{mg}$ & $0.23 \pm 0.05$ \\
\hline $\mathrm{Na}^{2}$ & $\mathrm{RDA}$ & $1300 \mathrm{mg}$ & $0.17 \pm 0.04 \mathrm{mg}$ & $0.01 \pm(*)$ & $0.15 \pm 0.04 \mathrm{mg}$ & $0.01 \pm(*)$ \\
\hline $\mathrm{Ca}^{2}$ & $\mathrm{RDA}$ & $1000 \mathrm{mg}$ & $3.21 \pm 0.19 \mathrm{mg}$ & $0.32 \pm 0.02$ & $0.64 \pm 0.07 \mathrm{mg}$ & $0.06 \pm(*)$ \\
\hline $\mathrm{P}^{2}$ & RDA & $700 \mathrm{mg}$ & $0.91 \pm 0.12 \mathrm{mg}$ & $0.13 \pm 0.02$ & $0.80 \pm 0.02 \mathrm{mg}$ & $0.11 \pm(*)$ \\
\hline $\mathrm{Mg}^{2}$ & $\mathrm{RDA}$ & $370 \mathrm{mg}$ & $1.36 \pm(*) \mathrm{mg}$ & $0.37 \pm(*)$ & $1.08 \pm 0.02 \mathrm{mg}$ & $0.29 \pm(*)$ \\
\hline $\mathrm{Fe}^{2}$ & RDA & $14 \mathrm{mg}$ & $0.03 \pm(*) \mathrm{mg}$ & $0.18 \pm 0.01$ & $0.01 \pm(*) \mathrm{mg}$ & $0.07 \pm(*)$ \\
\hline $\mathrm{Zn}^{2}$ & RDA & $9 \mathrm{mg}$ & $0.02 \pm(*) \mathrm{mg}$ & $0.20 \pm 0.08$ & $0.01 \pm(*) \mathrm{mg}$ & $0.16 \pm 0.03$ \\
\hline $\mathrm{Mn}^{2}$ & RDA & $2.0 \mathrm{mg}$ & $0.08 \pm 0.02 \mathrm{mg}$ & $4.25 \pm 1.1$ & $0.01 \pm(*) \mathrm{mg}$ & $0.53 \pm 0.27$ \\
\hline $\mathrm{Cu}^{2}$ & RDA & $900 \mu \mathrm{g}$ & $3.85 \pm 0.17 \mu \mathrm{g}$ & $0.43 \pm 0.02$ & $3.51 \pm 0.25 \mu \mathrm{g}$ & $0.39 \pm 0.03$ \\
\hline $\mathrm{Mo}^{2}$ & RDA & $45 \mathrm{mg}$ & $0.26 \pm 0.09 \mu \mathrm{g}$ & $0.58 \pm 0.21$ & $0.17 \pm 0.02 \mu \mathrm{g}$ & $0.38 \pm 0.07$ \\
\hline $\mathrm{Cr}^{2}$ & RDA & $30 \mathrm{mg}$ & $0.28 \pm 0.02 \mu \mathrm{g}$ & $0.93 \pm 0.08$ & $0.14 \pm 0.01 \mu \mathrm{g}$ & $0.48 \pm 0.04$ \\
\hline $\mathrm{Al}^{3}$ & TUI & $65 \mathrm{mg}$ & $0.16 \pm 0.02 \mathrm{mg}$ & $0.25 \pm 0.03$ & $0.07 \pm 0.02 \mathrm{mg}$ & $0.10 \pm 0.05$ \\
\hline $\mathrm{V}^{2}$ & TUI & $1800 \mathrm{mg}$ & $0.09 \pm(*) \mu \mathrm{g}$ & $0.005 \pm(*)$ & $0.09 \pm(*) \mu \mathrm{g}$ & $0.005 \pm(*)$ \\
\hline $\mathrm{Co}^{1}$ & TUI & $1400 \mathrm{mg}$ & $0.12 \pm(*) \mu \mathrm{g}$ & $0.01 \pm(*)$ & $0.13 \pm(*) \mu \mathrm{g}$ & $0.01 \pm(*)$ \\
\hline $\mathrm{Ba}^{4}$ & TUI & $1300 \mathrm{mg}$ & $19.33 \pm 5 \mu \mathrm{g}$ & $1.49 \pm 0.42$ & $3.38 \pm 1.2 \mu \mathrm{g}$ & $0.26 \pm 0.11$ \\
\hline $\mathrm{Ni}^{3}$ & TUI & $1000 \mathrm{mg}$ & $0.70 \pm 0.27 \mu \mathrm{g}$ & $0.07 \pm 0.02$ & $0.75 \pm 0.20 \mu \mathrm{g}$ & $0.08 \pm 0.23$ \\
\hline $\mathrm{Pb}^{3}$ & TUI & $250 \mathrm{mg}$ & $0.26 \pm 0.02 \mu \mathrm{g}$ & $0.11 \pm(*)$ & $0.18 \pm 0.02 \mu \mathrm{g}$ & $0.07 \pm(*)$ \\
\hline $\mathrm{As}^{3}$ & TUI & $150 \mathrm{mg}$ & $0.18 \pm 0.04 \mu \mathrm{g}$ & $0.12 \pm 0.03$ & $0.15 \pm 0.02 \mu \mathrm{g}$ & $0.10 \pm 0.02$ \\
\hline $\mathrm{Cd}^{3}$ & TUI & $65 \mathrm{mg}$ & $0.06 \pm(*) \mu \mathrm{g}$ & $0.10 \pm(*)$ & $0.06 \pm 0.01 \mu \mathrm{g}$ & $0.09 \pm 0.02$ \\
\hline $\mathrm{Ag}^{5}$ & - & $44 \mathrm{mg}$ & $0.11 \pm(*) \mu \mathrm{g}$ & $0.25 \pm(*)$ & $0.10 \pm(*) \mu \mathrm{g}$ & $0.22 \pm(*)$ \\
\hline
\end{tabular}

${ }^{1}$ FSA (2003); ${ }^{2}$ IOM (2001); ${ }^{3}$ WHO (1996); ${ }^{4}$ SCHER (2012); ${ }^{5}$ There are no data on the intake acceptable to humans, so the indicated value refers to the sum of the average intake of Ag with the standard deviation $\left(27+17=44 \mu \mathrm{g}\right.$ day $\left.{ }^{-1}\right)$ according to Hamilton and Minski (1972). $(*)=$ standard deviation below at 0.001 . 


\section{CONCLUSIONS}

The fruits have a more distinct elemental composition, hot-water solubility of elements and nutritional value than yerba mate leaves with variations among provenances depending on the element. In general, the fruits are poor in $\mathrm{N}, \mathrm{Mg}, \mathrm{Mn}, \mathrm{Ca}, \mathrm{Fe}, \mathrm{Ba}, \mathrm{Cr}, \mathrm{Al}$ and $\mathrm{Ag}$ and rich in $\mathrm{K}$ in comparison to the leaves. The results indicate greater variability in hot-water solubility of elements, but the solubility of $\mathrm{Fe}, \mathrm{Al}, \mathrm{Ca}, \mathrm{Zn}, \mathrm{Mo}, \mathrm{Pb}$, $\mathrm{Ag}$ and $\mathrm{Cd}$ present higher values in fruits that leaves. In terms of nutritional value, the intake of elements with the consumption of the yerba mate leaves and fruit as an infusion would contribute to the diet, especially by $\mathrm{K}, \mathrm{Mg}$, $\mathrm{P}, \mathrm{Mn}, \mathrm{Cu}, \mathrm{Mo}$ and $\mathrm{Cr}$, since it shows no health risk due to low contribution of undesirable elements. However, it is worth stressing that this remark is only hypothetical, keeping in mind that the fruits are not used in products intended for human or even animal consumption. Lastly, the intake of elements with the consumption of the yerba mate leaves in capsule form would contribute to the diet only via $\mathrm{Mn}$.

\section{REFERENCES}

BASTOS, D. H. M. et al. Yerba mate: pharmacological properties, research and biotechnology. Medicinal and Aromatic Plant Science and Biotechnology, 1(1):3746, 2007.

BASTOS, M. C. et al. Mineral content of young leaves of yerba mate. Pesquisa Florestal Brasileira, 34(77):63-71, 2014.

BAXTER, I. et al. Biodiversity of mineral nutrient and trace element accumulation in Arabidopsis thaliana. PLoS One, 7(4): e35121 (doi:10.137/journal. pone0035121), 2012.

BERTÉ, K. A. S. et al. Chemical composition and antioxidant activity of yerba-mate (Ilex paraguariensis A. St.Hil, Aquifoliaceae) extract as obtained by spray drying. Journal Agricultural and Food Chemistry, 59(10):55235527, 2011.

BURRIS, K. et al. Composition and bioactive properties of yerba mate (Ilex paraguariensis A. St.-Hill.): A review. Chilean Journal of Agricultural Research, 72(2):268-274, 2012.

CALDAS, E. D.; MACHADO, L. L. Cadmium, mercury and lead in medicinal herbs in Brazil. Food and Chemical Toxicology, 42:599-603, 2004.
CARON, B. O. et al. Biomassa e acúmulo de nutrientes em Ilex paraguariensis A. St. Hil. Ciência Florestal, 24(2):267-276, 2014.

COGOI, L. et al. Nutritional and phytochemical study of Ilex paraguariensis fruits. Journal of Chemistry, article ID $750623 ; 2013$.

\section{DIÁRIO OFICIAL DA UNIÃO. RESOLUÇÃO-DOU -} RDC n $\mathrm{n}^{\circ}-42$, de 29 de agosto de 2013.

\section{EMPRESA BRASILEIRA DE PESQUISA} AGROPECUÁRIA - EMBRAPA. Manual de métodos de análise de solo. 2. ed. Embrapa Solos: Rio de Janeiro. 2011. 225p.

FOOD STANDARDS AGENCY-FSA. Safe upper levels for vitamins and minerals. Expert Group on Vitamins and Minerals. United Kingdom, 2003. 360p.

HAMILTON, E. I.; MINSKI, M. J. Abundance of the chemical elements in man's diet and possible relations with environmental factors. Science of the Total Environment, 1(4):375-394, 1973.

HECK, C. I.; MEJIA, E. G. de. Yerba mate tea (Ilex paraguariensis): a comprehensive review on chemistry, health implications, and technological considerations.

Journal of Food Science, 72(9):138-151, 2007.

HEINRICHS, R.; MALAVOLTA, E. Composição mineral do produto comercial da erva-mate (Ilex paraguariensis $\mathrm{St}$. Hil.). Ciência Rural, 31(5):781-785, 2001.

HOPE, S. J. et al. Influence of tea drinking on manganese intake, manganese status and leucocyte expression of MnSOD and cytosolic aminopeptidase P. European Journal of Clinical Nutrition, 60(1):1-8, 2006.

INSTITUTO BRASILEIRO DE GEOGRAFIA E ESTATÍSTICA-IBGE. Produção agrícola municipal: culturas temporárias e perenes. Produção Agrícola Municipal, 2013. (40):1-102, 2014.

INSTITUTE OF MEDICINE-IOM. Dietry reference intakes for vitamin $\mathrm{A}$, vitamin $\mathrm{K}$, arsenic, boron, chromium, copper, iodine, iron, manganese, molybdenum, nickel, silicon, vanadium, and zinc. Washington: National Academy Press, 2001. 797p. 
JIN, C. W. et al. Lead contamination in tea garden soils and factors affecting its bioavailability.

Chemosphere, 59(8):1151-1159, 2005.

LV, H. P. et al. Contents of fluoride, lead, copper, chromium, arsenic and cadmium in Chinese Pu-erh tea. Food Research International, 53(2):938-944, 2013.

KARAK, T.; BHAGAT, R. M. Trace elements in tea leaves, made tea and tea infusion: A review. Food Research International, 43(9):2234-2252, 2010.

KOOLMAN, J.; ROEHM, K. H. Color atlas of biochemistry (2nd ed.). Stuttgart, New York: Thieme, 2005. 467p.

KRÖPPEL, M. et al. Differences in aluminium content of various tea powders (black, green, herbal, fruit) and tea infusion. European Chemical Bulletin, 1(9):382386-2012.

MARTINS, A. P. L.; REISSMANN, C. B. Material vegetal $\mathrm{e}$ as rotinas laboratoriais nos procedimentos químicoanalíticos. Scientia Agraria, 8:1-17, 2007.

MCKENNA, B. A. et al. Effects of $\mathrm{Ca}, \mathrm{Cu}, \mathrm{Al}$, and $\mathrm{La}$ on pectin gel strength: Implications for plant cell walls. Carbohydrate Research, 345:1174-1179, 2010.

MÉTRAUX, J. P.; TAIZ, L. Cell wall extension in Nitella as influenced by acids and ions. Proceedings of the National Academy of Sciences, 74(4):1565-1569, 1977.

REISSMANN, C. B.; RADOMSKI, M. I; QUADROS, R. M. B. Chemical composition of Ilex paraguariensis St. Hil. under different management conditions in seven localities of Paraná state. Brazilian Archives of Biology and Technology, 42:187-194, 1999.
SANTOS J. S. et al. Evaluation of some metals in Brazilian coffees cultivated during the process of conversion from conventional to organic agriculture.

Food chemistry, 115(4):1405-1410, 2009.

SCHER - Scientific Committee on Health and Environmental Risks. Assessment of the tolerable daily intake of barium. European Commission: Brussels, 2012, p. 13. Available in: <http://ec.europa.eu/health/ scientific committees/environmental risks/docs/ scher_o_161.pdf>. Access in: September. 14, 2015.

SCHMIDT, C. A. P. et al. Concentrações de metais pesados em grãos de café produzidos em lavouras sobre solos originados do basalto e do arenito Caiuá. Ciência Rural, 39(5):1590-1593, 2009.

SILVA, V. et al. Variáveis da acidez em função da mineralogia da fração argila do solo. Revista Brasileira de Ciência do Solo, 32(2):551-559, 2008.

VITTO, L. et al. Major and trace elements contents in crude drug and infusions of two South American species of Achyrocline (Asteraceae) named "Marcelas". Latin American Journal of Pharmacy, 28(4):552-559, 2009.

VULCANO, I. R. C.; SILVEIRA, J. N.; ALVAREZLEITE, E. M. Teores de chumbo e cádmio em chás comercializados na região metropolitana de Belo Horizonte. Brazilian Journal of Pharmaceutical Sciences, 44(3):425-431, 2008.

WHO - World Health Organization. Trace elements in human nutrition and health. Geneva: WHO Library, 1996. 360p.

WHITE, P. J. Ion uptake mechanisms of individual cells and roots: short-distance transport. In: MARSCHNER, P. (ed.). Marschner's mineral nutrition of higher plants. Ed. 3. Elsevier Science, 2012. p.7-47. 